\title{
Water Sensitive Development of New Towns -A Regional Development Approach
}

\author{
Dipanwita Chakravarty ${ }^{1}$, Vatrika Singh ${ }^{2}$, Trupti Kamat ${ }^{3}$ and Sandeep Sabharwal ${ }^{4}$ \\ ${ }_{1,2,3}$ Bharati Vidyapeeth College of Architecture, \\ ${ }^{4}$ Reliance Foundation
}

Email: dipanwita.chakravarty@gmail.com

ARTICLE INFORMATION

Received: February 28, 2018

Revised: April 12, 2018

Accepted: May 25, 2018

Published online: July 02,2018

Keywords:

Water sensitive development, regional planning, Integrated design, flood management, conservation of natural heritage.

DOI: http://doi.org/10.15415/cs.2018.61001

\section{ABSTRACT}

Water is an important natural resource which is becoming scarcer day by day. Conservation of water and exploring alternative sources is therefore important in the given context. The present paper addresses the issue of water sensitive development on a regional scale and tries to suggest skeletal guidelines for an action plan to be implemented as a part of national policy.

Also the paper aims to look at the entire profile of the rural base and adjoining urban areas along with the socio-economic characteristics, habitat conditions, settlement pattern, materials and technology incorporated for construction, successful case studies of revival of a few traditional water harvesting systems, the neglect in recent times, water sensitive development of hamlets on a regional scale and the role of architecture and planning in water sensitive development. It also explores the principles and strategies of run -off quality and quantity management along with flood management and integrated design that highlights economic, environmental and social benefits of such development.

The paper endeavors to emphasize the regional context in water sensitive development rather than a settlement specific context as it is a much holistic approach considering the local macro and micro climate, flora, fauna and the drainage pattern.

\section{The Present Crisis}

India has been facing acute water shortage over the past years with more than a quarter of its population severely deprived of water. The situation in $r$ ural I ndia is $b$ ad $w$ ith $f$ armers committing suicide, armed guard deployed to protect water and trains carrying millions of gallons of water to quench the thirsty areas. In Urban areas the situation is no better with most of the metropolis in India reeling under water crisis. Since two third of India's cultivable land is dependent on rain -fed irrigation food security is an important issue linked to water crisis. With subsidized electricity farmers draw up groundwater recording an annual fall of water table at the rate of $0.3 \mathrm{~m}$ to $4 \mathrm{~m}$ (The Economist May 25 ${ }^{\text {th }}$ 2016) Water starved regions often grow water hungry crops like paddy cotton and sugarcane. Water related violence have spread from Urban slums to sophisticated neighborhoods of Bangalore following the Cauvery water dispute. Following these footsteps it is not unlikely that water woes would have unprecedented consequences. The National Water Policy 2012 identifies that conservation, distribution and minimizing wastage through proper development and resource management is the key to address this problem The five identified goals of the Mission as enunciated by Ministry of Water Resources, River development and Ganga Rejuvenation, are Comprehensive water data base, water conservation, augmentation and preservation, attention to vulnerable areas, increasing water use efficiency and integrated water management.

\subsection{Why Conservation and Rain Water Harvesting}

India tops the list of countries with the greatest number of people being deprived of safe drinking water (The State of World's Water 2017), in spite of having a high average annual rainfall. It being the primary source of fresh water, the concept behind conserving water is to harvest it.

\section{The Traditional Water Harvesting Systems in India- Regional Level}

India, despite its different g eographical 1 ocations, w ide climatic diversity and varied cultural perspectives, has been traditionally conserving rain water in almost all parts of the country. These are century old practices many of which have been forgotten in recent times. The methodology of conservation in different parts of the country is different depending on local need and availability but the ultimate intent is conservation of rain water and storing it for use during drier months. A few practices that are commonly 
adopted in different parts of the country are Kul or channels carrying molten glacier water in Himachal Pradesh, Naula or surface water harvesting method typical to the hills of Uttaranchal, Khatris, Zobo or conservation of impounding run off in Nagaland and Eris in Tamil Nadu which have played major role in maintaining environmental balance as flood control systems, preventing soil erosion and top soil run- off, during heavy rainfall while recharging groundwater.

\subsection{Urban Level}

In the Urban context also water sensitive development was witnessed, starting from Harappan Civilization that focused on the Great Bath House and the drainage channels. The city of Dholavira located in Rann of Kutch, seen today as a fortified city set in harsh land, was once a metropolis with water conservation techniques from rain water harvesting consisting of large rock cut reservoirs, rock cut wells and huge stone drains. One of the most ornate structure in Gujarat the Rani ki Bav, at Bund is a magnificent example of ornate stonework around a stepwell for water harvesting. The Jahaj Mahal at Mandu, built by anonymous architect of Ghiyasuddin Khilji, the Delhi emperor incorporated several principles of Solar Passive Architecture and water sensitive planning such as placement of fenestration, use of rainwater, integration of landscape, design of opening and jaalis, with a mix of playfulness and elegance, where wind and water were woven through the built fabric.

\subsection{Case studies of successful revival of Regional Water Harvesting Systems}

Case Study 1: Watershed Management Kothapally: Farmers participatory integrated water management at Kothapally is a successful story of a community based innovative and replicable approach. Located in the semi arid areas which is characterized by variable and scanty rainfall, extremely low productivity and poor infrastructure development, widespread, poverty and mal-nutrition, watershed management is considered as an ideal approach involving the Government and local communities and providing required technical support (Wani S., et al., 2015). The process involved carrying out a baseline survey of the soil typology, depth and cropping pattern, soil typology, water level, nutrient management and pest control practices followed by the villagers and socio-economic and demographic characteristics of the farmers. Then community based associations like watershed associations, watershed communities, self help groups, user groups and women SHGs were formed. They were then involved in construction of check dams, terrain management and plantations.

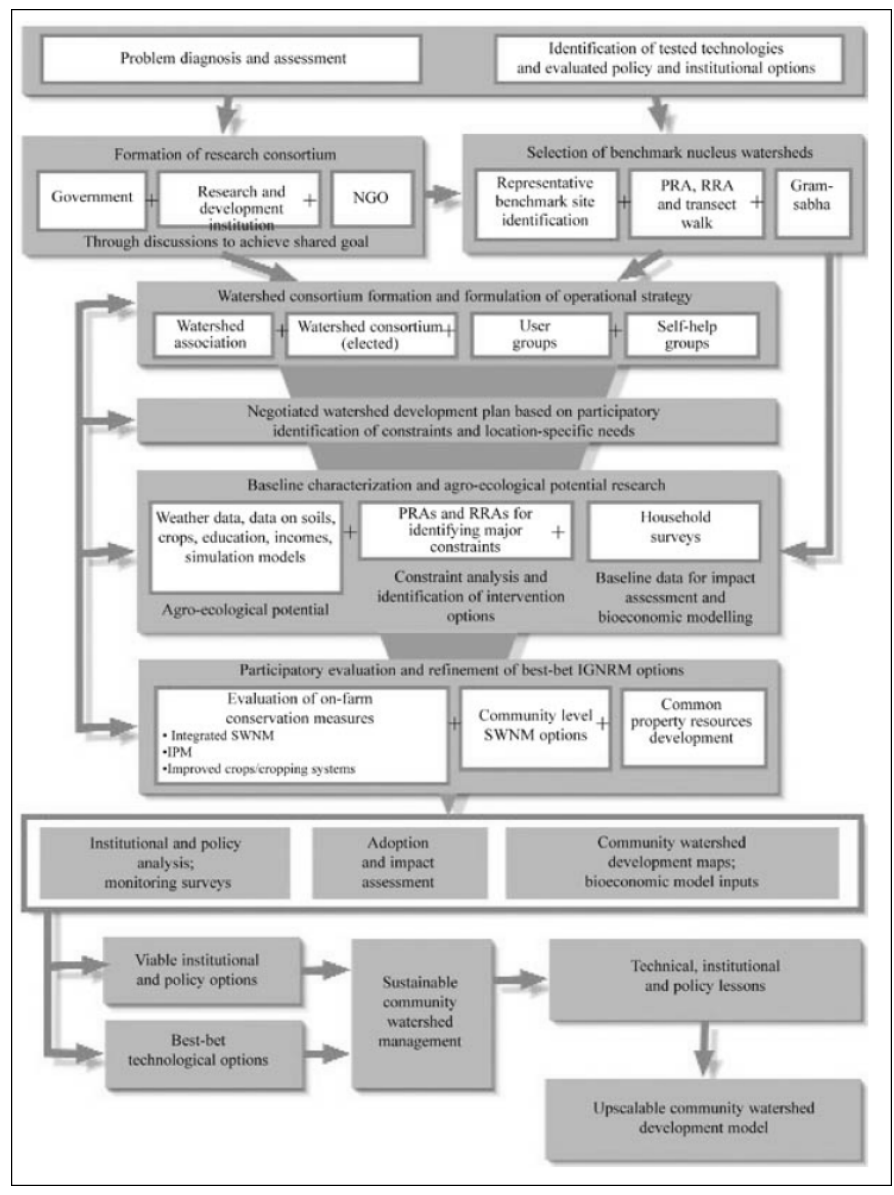

Figure 1. Community management strategy for water conservation (source: Author)

The success of the programme lied in massive community participation, ownership of the community, detailed participatory rural appraisal exercise, mapping of natural resources and comprehensive baseline data analysis. The watershed management plan was devised by networking natural drainage patterns. The hydro-geological $\mathrm{m}$ ap w as studied and accordingly a watershed management plan was proposed incorporating water harvesting structures at strategic locations and the entire watershed management plan was implemented in phases. Soon the ground water table improved as shown in the graph (Fig:3)

\section{Case Study 2: Shiv Ganga Model Jhabua}

Jhabua is an extremely poor tribal district in North western Madhya Pradesh. Inhabited by mostly Bhils and Bilalas, the area consists of semi arid plateaus with very scanty rainfall. The main impediment against development in this region, is scarcity of water. The villagers can only take one kharif crop per year which results in migration resulting in non availability of education and health care facilities. 


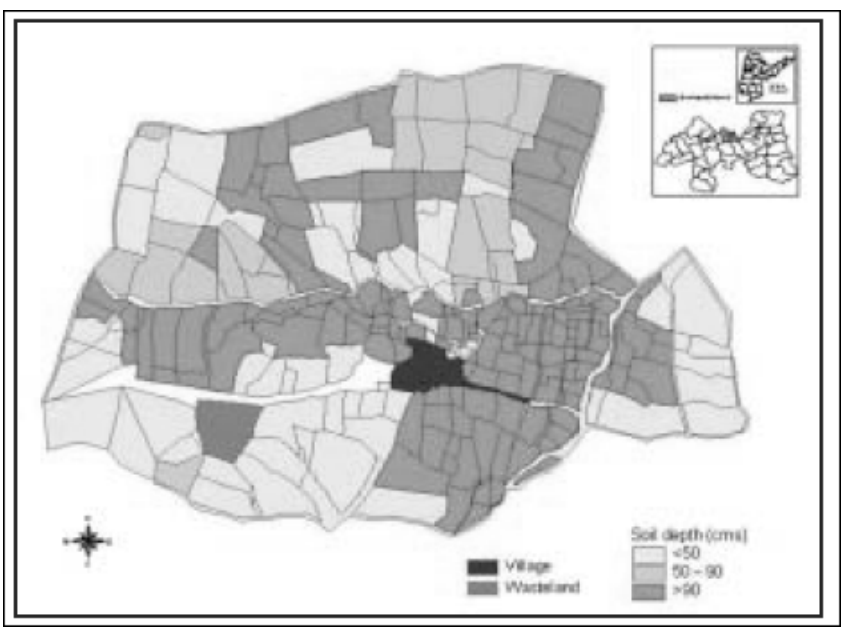

Figure 2: Identification of management plan (Source: Journal of SAT Agricultural Research)

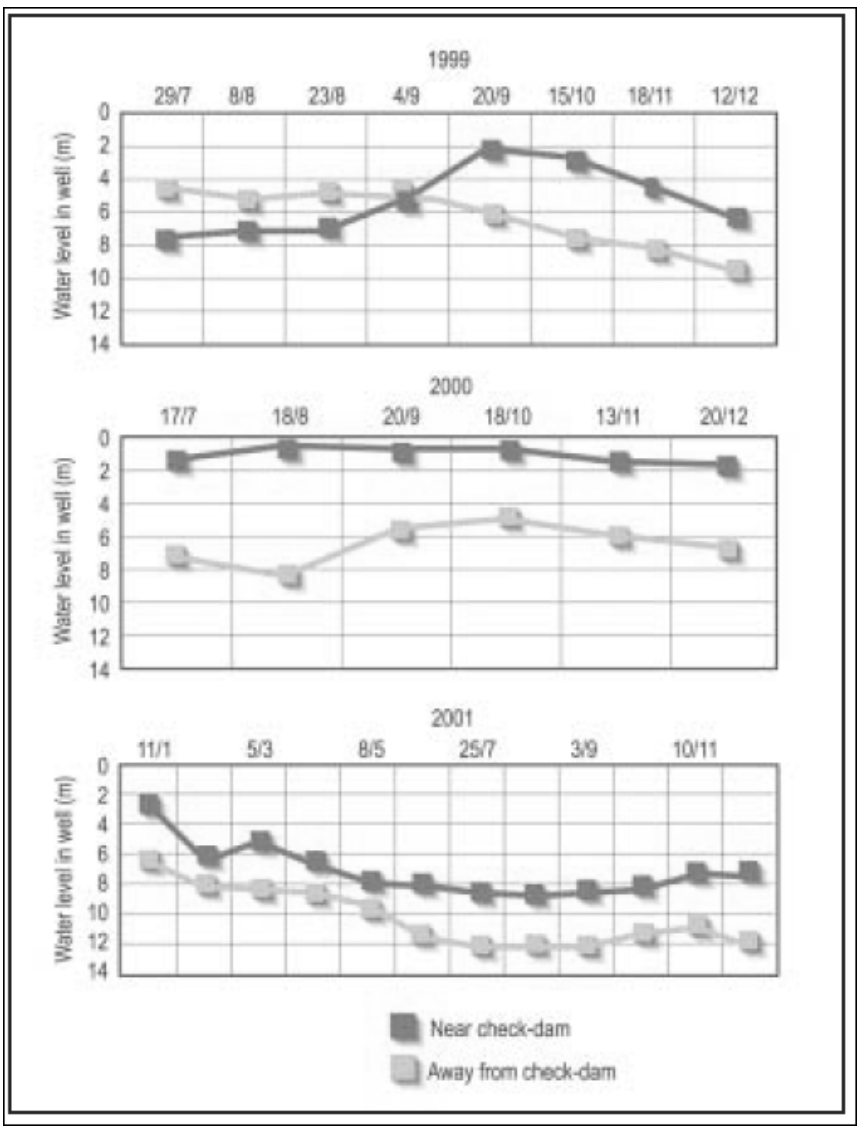

Figure 3. Graphs of Ground Water Level (Source: Author)

A successful water harvesting initiative has been pioneered by the Shiv Ganga model through grass root mobilization and voluntary participation of the local inhabitants with the help of a strong community network.
The local Governing council, Government and intellectuals from diverse background come together to learn from participative practices in an annual congregation called Halma to witness the largest watershed management. The geographical terrain of Jhabua is such that (fig:4) it consists of undulating landscape with sparse vegetation. The water table had been low and most of the sources of fresh water used to get dry during summer causing severe shortage of drinking water Under the able leadership of Shri Mahesh Sharma, 27 Ponds, 68 Wells, 140 Check Dams/ Stop Dams, 89 hills Trenches on 227 hills with Gulley control, 666 hills with Contour bunds and 426 nala bunds had been constructed along with 650 other bunds implemented by 1600 plus volunteers from 1400 target villages.



Figure 4. Location of Jhabua (Source: Maps of India.com)

\subsection{Inferences}

These examples show that water management done on a regional level addresses the concerns of water storage and distribution in a more holistic and comprehensive way. This is because water is meticulously collected and managed over a larger regional area where

- Contour, water circulation pattern and drainage channels can be incorporated in zonal level water sensitive design.

- A network of minor catchment areas incorporating bunds and check-dams for water retention and distribution may be initiated

- Seasonal variation of water demand may be addressed by storing and supplying it whenever required.

In thickly populated Urban areas with huge paved surfaces, buffer zones or absorption areas may be provided by leaving intermittent green zones and holding ponds and water absorptive paving surfaces. 


\subsection{Benefits of Water-Sensitive Development}

There are economic, environmental and social benefits of water sensitive development.

Economic Benefits-Water sensitive development results in capital cost saving, construction cost saving, development cost saving, maintenance cost saving, improved resource utilization and improved market value.

Environmental Benefits-It maintains the hydro-geological balance, sensitive area protection, waterways restoration impact reduction, enhancement of natural habitat and ground water recharge.

Social Benefits-The social benefits may include inclusive design and decision making by various communities, visually appealing urban residential landscapes, to link communities and open spaces and mitigating urban heat island effect.

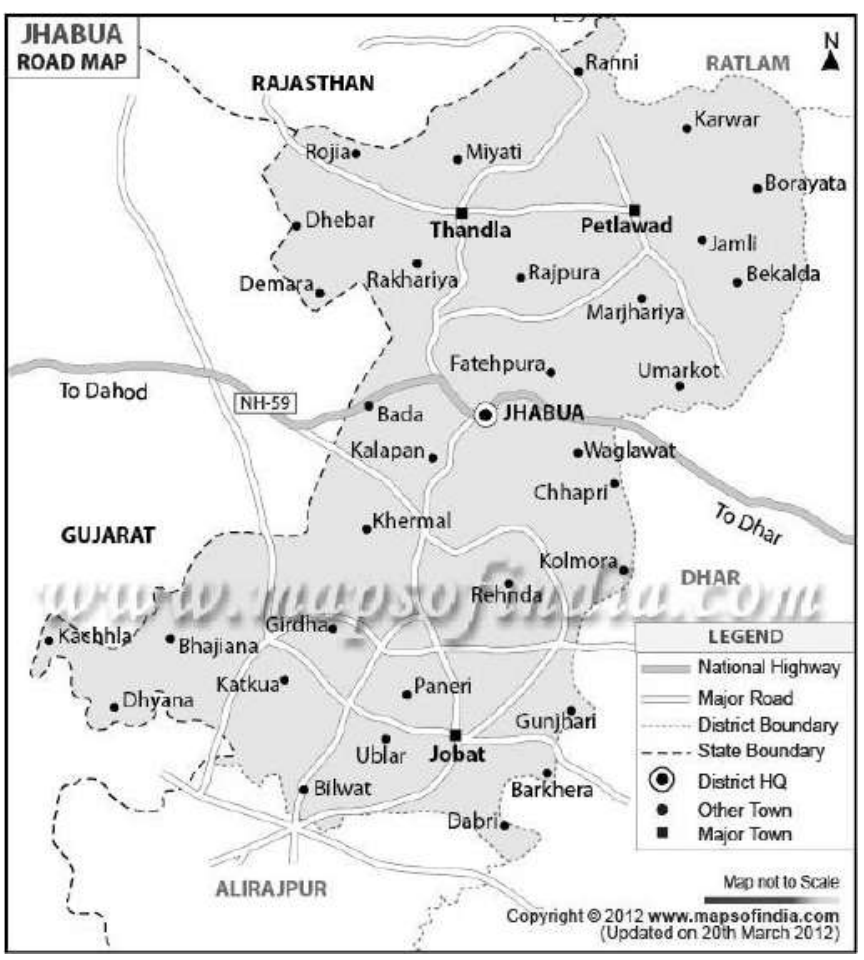

Figure 5. Agricultural practices in Madhya Pradesh (Source: Maps of India.com)

\section{Urban Development -The Neglect in Recent Times}

Most of the ancient Indian cities grew around riverbank and many developed as harbors, nourishing trade and commerce along the coastline. Varanasi, one of the oldest cities along the Ganges is still thriving as a Living heritage. In order to ensure that a source of water was perennial, its catchment was protected. The river systems in ancient India were celebrated and respected. Although the medieval era witnessed political turbulences but organic growth and development occurred barring a few examples. In the recent times Industries and employment opportunities dictated the growth and development of new towns. Polis slowly became metropolis and megalopolis and the crunch on natural resources was felt. To add to this, havoc was created by pollution, reclamation and neglect of existing water channels and clogging caused by unprecedented dumping of plastic and other solid waste. Moreover huge amount of urban paved surface and storm water drains stopped the rain water from percolating and drained them directly to the sea causing acute shortage of fresh water and causing floods during torrential rain.

\subsection{Water Sensitive Approach to Urban Development-Regional scale}

While locating a city and delineating its growth poles it is imperative that the regional perspectives are considered. The development should be such that the natural drainage channels and catchment area is preserved and the local flora and fauna should co-exist with it. Also replenishment of natural resources or sustainable development should be the focus. Every city or urban fringe should be surrounded by a buffer zone for regenerating its natural resources like catchment area for rain water harvesting holding ponds, thick vegetative cover etc. The catchment area would be based on natural contour that forms a watershed with a network of check dams, drainage channels and reservoirs that suffices the water requirement of the future projected population.

The following approach may be adopted for water sensitive urban development on a regional scale.

- A thorough knowledge of the existing land strata, soil typology, vegetation (water loving plants),geological maps and cross sections give important clues while planning. Integrated management of all water resources, coordinated planning and development, land use planning based on seasonal and annual water availability can be identified.

- Water availability can direct the planning of infrastructure related to educational, transport, health and civic facilities and identify the appropriate land accordingly.

- Replenishment of water in natural water reservoirs should be aimed such that it suffices the future needs of projected population in a particular region.

- Treatment of used water before disposal is absolutely necessary involving clarification, reduction of BOD including carbon filtration and electro-dialysis reversal. 
- Recycling of water should be emphasized as much as possible before treatment to reduce the treatment load.

- A network of small water harvesting structure to be planned on a regional scale, which would not be affected by urban development and sprawl.

- Reclamation of existing water bodies and drainage channels should be avoided as much as possible.

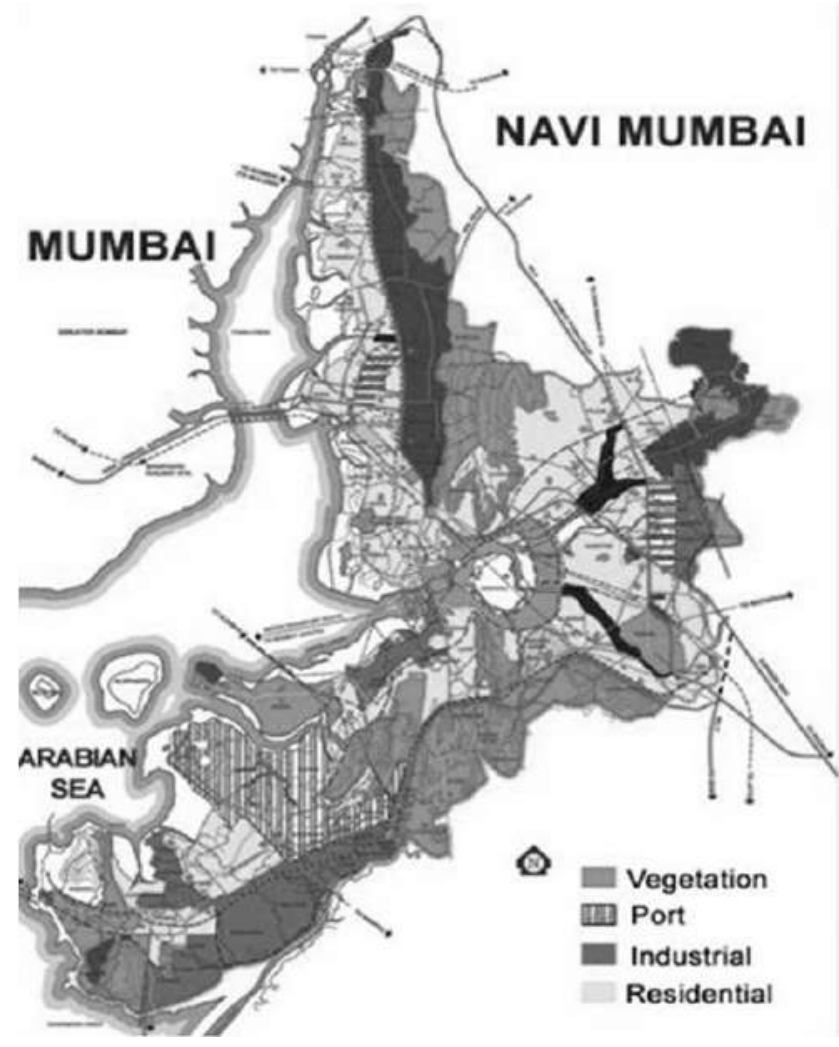

Figure 6. Map showing coastline and green buffers in Navi Mumbai (Source: CIDCO Navi Mumbai DP)

\subsection{Water sensitive approach to Urban Development -Urban Scale}

Water sensitive approach to urban development would aim at conservation of fresh water, optimum utilization of water through conservation and recycling, sensitive development encouraging percolation, and non depletion of water table, proper treatment and disposal of used water to reduce pollution and segregation of contaminated and non -contaminated water. Zoning of urban areas and land use planning should be such that mixed-use neighborhoods and transit-oriented centres are encouraged. This provides the basis for the development of areas in which population is expected to grow, so the future projected population and water needs are in tandem. A few other considerations may be
- The residential zones could be planned such that they have intermittent green pockets connected by continuous green corridor and drainage channels for percolation, collection and storage of rain water.

- In each individual plots and building units, rain water collection tanks along with required infrastructure should be installed and paved surfaces should be reduced as much as possible. Also the drainage layout should be done such that the fresh water collected from rains could be reused for landscape, washing and other activities.

- In addition to this, complete and partial recycling should be encouraged and water saving gadgets and devices installed.

- Monitoring of usage of water through water meters should be encouraged.

\subsection{The case of Navi Mumbai}

Navi Mumbai is a new town where principles of Water sensitive urban design are witnessed in the overall planning as well as in the detailing of various nodes and sectors. Navi Mumbai experiences high average annual rainfall. It has a peculiar setting, with creek on one side with a long coastline which houses vast stretches of mangroves, paddy fields, salt pans and fresh-water lakes; and hill ranges bounding it on the other side. About 20\% land is low lying and reclamation of these areas is not feasible economically and environmentally. Thus, combination of high rainfall in the rainy season along with the high tide in the creek makes the site vulnerable to flooding and efficient disposal of storm water is vital. In the planning of Navi Mumbai, CIDCO (City and Industrial Development Corporation) has planned its land use considering the water shed area, minimizing the damage to the Natural drainage of the site. From the point of view of water management, the infrastructure of the city was developed in a manner to have separate drainage lines for storm water and sewage drain.

In coastal areas there is inevitable incursion of salt water which contaminates the fresh water bodies leaving them unfit for consumption. CIDCO has been taking steps to mitigate the impacts of ingress of sea water by constructing uniquely designed holding ponds with unidirectional flap gates. The ponds store water during high tides releasing them during low tides. 30 holding ponds were constructed defined with trees. Also 16 detention ponds were designed that help regulate the flow of water runoff from the hills, which would have otherwise caused devastation during high tides. The ponds are only functional in the monsoon months. The treated effluent from STPs gets used for landscaping and maintenance of gardens. Unlike Navi Mumbai, Mumbai does not have these features, which makes it vulnerable during monsoon months. 


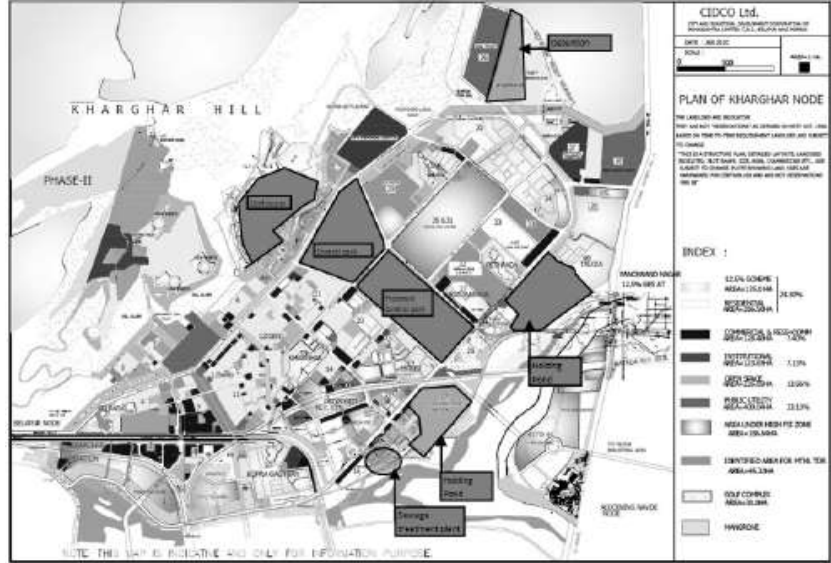

Figure 7. Map showing drainage channels, retention pond, holding ponds. (Source: CIDCO Kharghar node DP)

\section{Planning of New Towns}

The planning of new towns should start with a regional approach with an integrated water management system extending from the regional catchment scale to the site specific built form including an alternative water source which could be surface water, ground water, recycled waste water, storm water or desalinated sea water focusing issues of local scale within the built fabric. It should be adopted right from the land-use planning stage focusing on conservation of bio-diversity and ecological integrity. Water should be prevented from adverse pollution and opportunities for safe re-use should be explored. Protection of public health and community values should be incorporated while decision making. A through cost benefit analysis should be done from the preliminary stage and indigenous cultural relationship to water should be recognized.

The following principles may be adopted at strategic level

- Run-off quality-Water sensitive design may be implemented to manage the urban run-off quality to mitigate environmental degradation by reducing the total suspended solids by $75 \%$, phosphorus by $65 \%$ nitrogen by $50 \%$ and total gross pollutants by $90 \%$. (As enunciated in Environment Protection Act 1986)

- Run off Quantity-The hydrological impact of built environment on watercourses and their eco-systems should be minimized. For waterway protection the rate of run-off discharged from the site should be managed so that it does not exceed the pre-urban development of 1 year average recurrence.

- Flood management-For development and other relevant infrastructure, systems should be devised that will drain runoff to an existing publicly managed drainage system.

- Integrated design-The approach to design should be integrated such that achievement of multiple outcome is possible for efficient habitat development along with amenities, efficient energy use and reduction of greenhouse emissions with engagement of stakeholders at appropriate stages of planning, designing, constructing and managing.

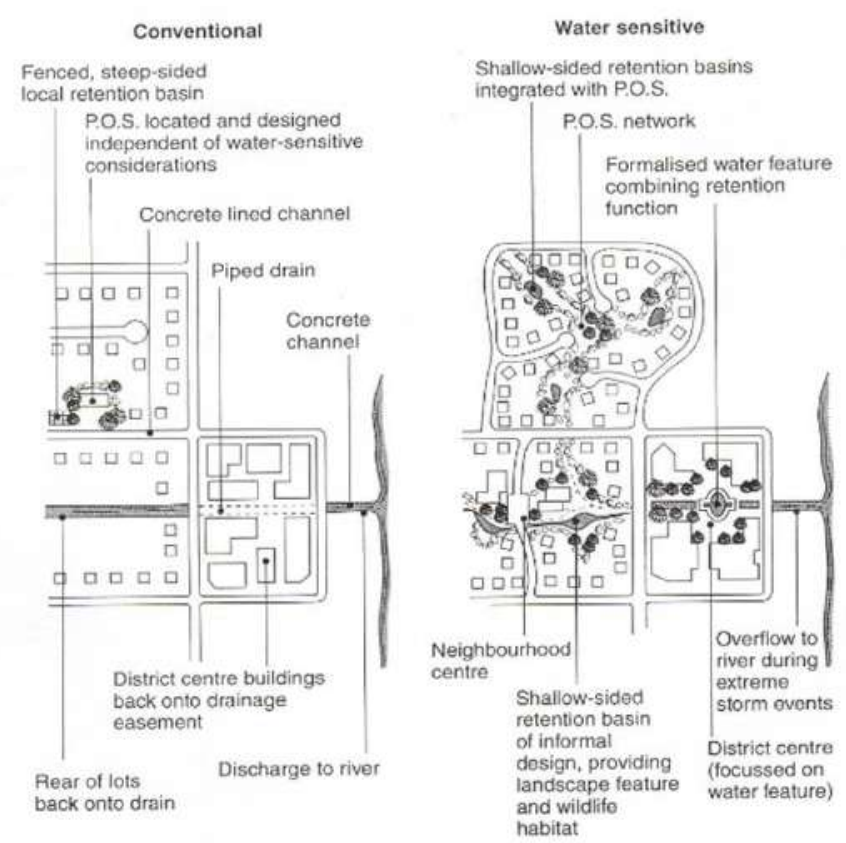

Figure 8. Schematic layout of normal development versus sensitive development. (Source: Whelnas et. al., in Engineers Australia 2006)

\subsection{Adopting Suitable Planning, Design and Management Principles}

- Defining land for an integrated storm water management system.

- Defining developable and non developable lands.

- The protection of public open space networks including remnant vegetation, natural drainage channels, recreational and cultural spaces and environmental features.

- The selection of options for use of water conserving measures at design level for road layout, building design, services that are looped etc.

A comparison of water sensitive development verses normal development as implied in figure 7 shows that water sensitive development focuses on neighbourhoods with interconnected greens and buffer spaces. 


\subsection{Evaluation of parameters for water sensitive development}

- The hydraulic performance options may be evaluated by estimating the percentage of flow treated or bypassed and checking levels.

- The water quality performance can be ascertained by inflow/outflow concentrations and load captured.

- The economic measures along with capital cost, maintenance and potential savings, infrastructure investments, land costs and opportunity costs to be analyzed.

- Ecological parameters including flora, fauna and ecosystem health to be monitored

- Public health like pathogen level and other potential harmful compound which may be present in recycled storm water and waste water to be assessed

- Social, cultural, aesthetic and community impact like photographic records and resident surveys to be collected.

(Water Sensitive Urban Design: A National Guide, Australia)

Based on the above planning strategies, practices and evaluation parameters an Action Plan may be devised on National level as under-

\subsection{Action Plan}

- Establish National level and State Level Frameworks to adopt Water sensitive performance principles in Government and privately managed infrastructure projects.

- Ensure Water sensitive development is supported in the land-use planning stage.

- Support Water sensitive development in the Building approval process.

- Align the principles and policies of Water Sensitive design with the Environment Protection Act 1986.

- In the National Skill Enhancement Programme, provide a dedicated curriculum and team for capacity building and management of sustainable practices.

- Provide continuous engagement of the National Policy through State nodal agencies, local Government and industry for appropriate implementation.

- Engage relevant research bodies for improved information and guidance.

- Ensure alignment between Natural Resource Management (NRM) and Water sensitive design objectives.

- Promote water sensitive urban design in catchment based storm water management plans

- Promote Water sensitive design in new developments like arterial road, major Government infrastructure projects and redevelopment and renewal of existing State owned infrastructure.
- Establish suitable process of reporting, monitoring and evaluation.

\subsection{A Few Endeavors Already Undertaken by Government}

Maharashtra has already pledged to be the first state to evolve an integrated water plan including amalgamation of five major river basins for better co-ordination and distribution of water. The plans built on five parameters will include structural measures, operational measures, watershed management, demand management and equitable distribution as enunciated by Government regulations.

\section{Conclusion}

While rural areas have huge potential for water sensitive development on a regional scale the development in urban areas is comparatively constrained and therefore needs to be streamlined from beginning. These issues should be immediately recognized by urban planners and incorporated in the development of new towns and smart cities.

- Thus there is a need for a National Framework on water Sensitive Development of New Towns.

- The framework may incorporate diversity of climate, topography and water availability but should focus on decentralized collection and storage and minimizing wastage.

- The land use planning and zoning of new town should focus on water sensitive development Watershed management techniques need to be adopted for harvesting, channelization and distribution of rain water following the natural contour and drainage pattern with least impact on the local flora and fauna.

- Management of water in Urban areas may incorporate site specific techniques like enhancing percolation, seasonal collection, recycling and metering. Also decentralized approach to water management and treatment and exploring alternative sources of water rather than complete dependence on municipal supply should be encouraged.

- The contemporary planning practice may incorporate traditional techniques like network of ponds, urban centers incorporating bawries (stepwell), planning along water channels etc, more emphasis on promenade development, retaining natural edges of water channels and integrating water bodies visually and ecologically to the city's development

\section{References}

A Look at India's water harvesting practices, Centre for Science and Environment, (2017, May 15), Retrieved 
from http://www.rainwaterharvesting.org/Rural/ Traditional3.htm

Centre for Technology alternatives for Rural Areas, Indian Institute of Technology, Bombay, Progenies of Ekalavya: A report on Visit to Jhabua district of Madhya Pradesh.

Department of Environment, Water and Natural Resources: Government of South Australia (2014)Water Sensitive Urban Design: Creating more Liveable and water sensitive cities in South Australia.

Evaluating Options for Water Sensitive Development- A National Guide. Government of Australia

Mishra Anupam, Aaj Bhi Khare hai Talaab

Rain water harvesting.org: Centre for Science and Environment.

Report of the Ministry of Water Resources, River Development and Ganga Rejuvenation

Sapkota, M., Arora, M., Malano, H., Moglia, M.; Sharma, A., George, B., Pamminger, F. An overview of hybrid water supply systems in the context of urban water management: Challenges and opportunities. Water 2015, 7, 153. [CrossRef]

Shah Shikha (2015) Traditional Water Conservation Methods in India

Sharma, A. K., Cook, S., Tjandraatmadja, G., Gregory, A. Impediments and constraints in the uptake of water sensitive urban design measures in greenfield and infill developments. Water Sci. Technol. 2012, 65, 340-352. [CrossRef] [PubMed]

Wani, S. P., Singh, H. P., Sreedevi, T. K., Pathak, P., Rego, T. J., Shiferaw, B., \& Iyer, S. R. (2003). Farmerparticipatory integrated watershed management: Adarsha watershed, Kothapally India-an innovative and upscalable approach. Journal of SAT Agricultural Research, 2(1), 1-27.

Whc.unesco.org/en/tentativelists/5892/

www.CIDCO.Maharashtra.Gov.in/NM_Physical_ Infrastructure.aspx 